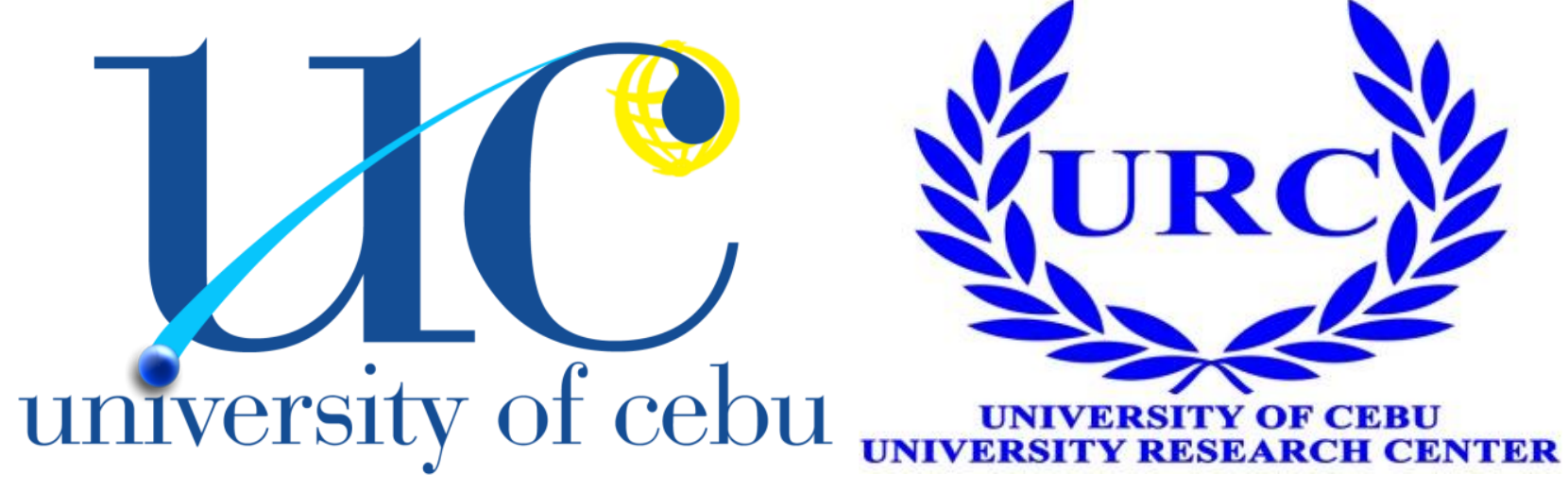

\title{
UNIVERSITY OF CEBU RESEARCH CENTER MANUAL
}

\section{VOL. 1, NO. 1, JUNE 2013 ISSN 2243-7568}

\section{DR. MAURO ALLAN P. AMPARADO UNIVERSITY RESEARCH DIRECTOR EDITOR-IN-CHIEF}




\section{UNIVERSITY OF CEBU \\ UNIVERSITY RESEARCH CENTER \\ UNIVERSITY OF CEBU \\ VISION, MISSION, GOALS AND CORE VALUES \\ VISION}

Democratize quality education.

Be the visionary and industry leader.

Give hope and transform lives.

\section{MISSION}

University of Cebu offers affordable and quality education responsive to the demands of local and international communities.

University of Cebu commits to:

- Serve as an active catalyst in providing efficient and effective delivery of educational services;

- Pursue excellence in instruction, research, and community service towards social and economic development as well as environmental sustainability;

- Acquire, disseminate and utilize appropriate technology to enhance the university's educational services; and,

- Foster an organizational culture that nurtures employee productivity and engagement.

\section{INSTITUTIONAL GOALS}

1. To offer programs that are relevant, holistic and compliant with institutional, regulatory, industry and accreditation standards that will develop life-long learners.

2. To develop social awareness, responsibility and accountability among stakeholders anchored on instruction, research and production.

3. To complement the academic programs with holistic and integrated student personnel services.

4. To develop a pool of qualified, professional and motivated faculty in the areas of instruction, research and community extension. 
5. To ensure effective administration and supervision of instructional and learning resources in support of the academic programs.

6. To provide an environment that is safe, functional and conducive to teaching, learning and working.

7. To ensure operations which are collaborative, sustainable, efficient and effective in meeting the needs of the institution and its stakeholders.

\section{CORE VALUES}

- Innovation. We embrace change and technological advancement to improve lives.

- Camaraderie. We live together in the spirit of love, harmony and respect for the dignity of the human person.

- Alignment. We value the common good and appreciate oneness, fairness and consistency.

- Respect. We practice professionalism at all times and abide by the university's guiding principles.

- Excellence. We are driven and committed to become the finest.

\section{UNIVERSITY OF CEBU HYMN}

'Mid these fair Visayan Isles,

'Neath these azure blue skies,

Stands UC, our Beloved,

Lofty in all her glory.

Spark of wisdom, hope and joy,

Always kindling in our hearts,

Thy precious name, thy glorious fame,

Will shine through all eternity.

Thy name shall ever be our guide,

Thy light, our inspiration,

Keep up the light a-glowing bright,

To thy portals, dear Alma Mater.

Hail! Praises be to thee,

Onward show us the way,

Faithful and true, we'll always be,

To thee our Alma Mater dear. 


\section{UNIVERSITY OF CEBU \\ UNIVERSITY RESEARCH CENTER \\ URC DEPARTMENTAL OBJECTIVES}

In consonance with the Vision, Mission, Institutional Goals and Core Values of the University, the University Research Center aims to achieve the following objectives:

1. To intensify the research capability of the faculty members and students.

2. To manage the conduct of institutional faculty researches.

3. To monitor the production of student researches.

4. To assist faculty members in the accomplishment of externally-funded research projects.

5. To conduct colloquia for the dissemination of research findings.

\section{URC PERSONNEL}

Dr. Mauro Allan P. Amparado

University Research Director

Dr. Judy Ann F. Gimena

Campus Research Coordinator, UC-Banilad

Ms. Danielita B. Patindol

Campus Research Coordinator, UC-LM

Dr. Rosielyn D. Tan

Campus Research Coordinator, UC-METC 


\section{UNIVERSITY OF CEBU \\ UNIVERSITY RESEARCH CENTER \\ RESEARCH AGENDA FOR INSTITUTIONAL \\ FACULTY RESEARCH SY 2011-2012 TO SY 2015-2016}

\section{Area 1. Philosophy and Objectives}

1. Evaluation of the University Goals, Objectives and Core Values.

2. Students' awareness on the Vision-Mission Statement.

3. Awareness and acceptance of the VMGO among partner communities.

\section{Area 2. Faculty}

1. Teaching Styles of the University of Cebu Faculty.

2. Faculty Performance Evaluation.

3. Evaluation of the Ranking System.

\section{Area 3. Instruction}

1. Insights on Vertical Articulation.

2. Matching competencies of academe and industry.

3. Integration of Information and Communications Technology in Instruction.

\section{Area 4. Library}

1. Library Services and Utilization.

2. Awareness and Utilization of the Online Public Access Catalog.

3. Faculty Participation in the selection of library collections.
Area 5. Laboratory
1. Utilization of Laboratory Facilities, Equipment and Supplies.
2. Maintenance and Repair System of Laboratory Facilities.
3. Customer Satisfaction of Laboratories. 


\section{Area 6. Physical Plant and Facilities}

1. School Hazards and Counter Measures.

2. Drainage and Sewage Disposal Facilities.

3. Group Assembly, Athletic and Recreational Activities.

\section{Area 7. Student Personnel Services}

1. Customer Satisfaction of the Student Personnel Services.

2. Training needs of working scholars.

3. Tracer Studies of graduates.

\section{Area 8. Social Orientation and Community Involvement}

1. Involvement of Faculty and students in Community Extension Programs.

2. Evaluation of Community Extension Programs.

3. Needs Assessment of partner communities.

\section{Area 9. Organization and Administration}

1. Evaluation of the Admissions Program.

2. Orientation Program for students.

3. Training Needs of Administrators and Department Heads.

\section{Area 10. Research}

1. Research Capability of the University of Cebu Faculty.

2. Implementation of Faculty Research proposed outputs.

3. Research Interests of the Faculty based on Central Visayas Agenda.

Note: Research is a separate area for Graduate School accreditation. 


\section{UNIVERSITY OF CEBU \\ UNIVERSITY RESEARCH CENTER \\ DEPARTMENTAL RESEARCH AGENDA \\ FOR SY 2011-2012 TO SY 2015-2016}

\section{A. COLLEGE OF BUSINESS ADMINISTRATION AND ACCOUNTANCY}

1. Environmental impact of prevalent consumption habits and production practices

2. Local area surveys on the prevalence of habits and practices conducive to productivity

3. Customer satisfaction studies

4. Implementation of minimum wage laws and its impact on firm productivity

5. Manpower demand-supply in the local business sector (e.g. BPO, Tourism, ICT, Manufacturing) and its intervention programs (e.g. industry-academe linkages)

\section{B. COLLEGE OF COMPUTER STUDIES AND COLLEGE OF COMPUTER ENGINEERING}

1. ICT based product development

2. The impact of ICT sector development and culture

3. Demand studies ICT product services

4. Enhancing ICT based repository of research abstracts

5. ICT initiatives of LGUs e.g. community E-centers in the region

\section{COLLEGE OF CRIMINAL JUSTICE}

1. Addressing Family/Social Health Issues

2. Local Area Studies of Urban Social Problems and Policy Options

3. Social Infrastructure: Demand and Supply Studies

4. Human Mobility Studies

5. The Dark Side of Tourism 


\section{COLLEGE OF CUSTOMS ADMINISTRATION}

1. Cost and benefits of National Government Agency operations in Bureau of Customs

2. Corruption: incidence perception and attitude

3. Issues and advocacies of the business sector on Governance, Trade and Investment

4. Review studies: Implementation of Legislation

5. Studies on social marketing programs

\section{E. COLLEGE OF EDUCATION AND COLLEGE OF ARTS}

1. Poverty Reduction Program

2. Environmental Programs

3. Literacy Studies

4. Studies on Cultures of Influence Groups

5. Organizational Development for Improving Effectiveness of Education Services

\section{F. COLLEGE OF ENGINEERING}

1. Demand and Supply studies; fitness and responsive of social infrastructure needs of local areas including vulnerable population

2. Demand studies of ICT products and services

3. ICT initiatives of LGUs, e.g. community E-centers in the region and effectiveness

4. Sectoral ICT projects: their usefulness in knowledge sharing technology dissemination

5. Conduct of monitoring R\& D results utilization: Technology, Transfer and Commercialization

\section{G. COLLEGE OF HOTEL AND RESTAURANT MANAGEMENT}

1. Local Development implications of an open-skies policy at the Mactan-Cebu Airport 
2. The Role of LGUs in tourism marketing and investment promotion: impacts and issues

3. Domestic tourism programs in local areas

4. Making ecotourism work in local areas

5. Social and economic impacts of tourism development transportation and communication in local areas

\section{H. COLLEGE OF MARINE ENGINEERING AND COLLEGE OF MARINE TRANSPORTATION}

1. Impact of the International Apprenticeship Program of the NSA Scholars

2. Affects of Urbanization to the Coastal Near Cebu City Ports

3. English Proficiency of the Maritime Students

4. Employability Rate of the Non-Scholars Maritime Students

5. A Comparative Study on HIV Cases for both Domestic and International Seafarers

\section{COLLEGE OF NURSING}

1. Improving the Health and Nutrition Status among: Infants, Children, Mother and Elderly

2. Addressing Prevalent Health issues on: PTB, dengue and diarrhea

3. Addressing Family/ social Health issues: Adolescent Substance Abuse (drugs, smoking, alcohol); Drug Abuse; Domestic Violence; Child Abuse

4. Nutrition studies

5. Community Services for health, children and family, care for the elderly, people with disabilities, youth development, welfare and support, housing, employment and training 


\section{UNIVERSITY OF CEBU \\ UNIVERSITY RESEARCH CENTER}

\section{STANDARD PROCEDURE NUMBER 1 INSTITUTIONAL FACULTY RESEARCH GRANT}

1. Proponent. All Full-time regular and probationary employees may avail of the Institutional Faculty Research Grant. A Faculty Research may be an individual endeavor or team effort (2 employees only). Administrators, Deans, Chairpersons and Department Heads may apply for institutional faculty research and shall serve as the junior researcher or the $2^{\text {nd }}$ author.

2. Nature of Research Project. Research projects shall be institutional (campus-wide) rather than departmental. This means that sampling shall be taken from all departments/colleges, proportionate to size. Research project shall be anchored on Faculty Research Agenda.

3. Application and Approval of Research Project. Faculty Researcher submits Institutional Faculty Research Grant Application Form (Standard Form Number 1) with title, rationale of the study, statement of the problem, methodology and budget. The form has to be signed by the following: Researcher; Program Research Coordinator (PRC) of his/her department; Dean/Chairperson; Campus Research Coordinator (CRC); Campus Affairs Director (CAD); and University Research Director (URD). The URD submits the application to the Vice Chancellor for Academic Affairs (VCAA) and Chancellor.

4. MOA Signing. Upon approval of the Chancellor, faculty researcher is requested to sign the Memorandum of Agreement (MOA) and he/she will be provided a copy of Standard Procedure Number 1. MOA shall indicate amount of grant (e.g. P25,000.00 as of SY 2013-2014).

5. Chairman, Adviser and Members. The URD will serve as Chairman. PRC will serve as adviser. If the research project is conducted by the PRC, the Dean/Chairperson will act as adviser. All CRCs will sit as members of the panel.

6. Proposal Hearing. Upon approval by VCAA, the Faculty Researcher will defend his/her problem and methodology to a panel of experts (Chairman, Adviser and Members) within 5 months from the time of approval.

6.1. The Researcher shall submit 4 copies of the research proposal to $\mathrm{URD}$ at least 7 days before the schedule of the proposal hearing.

6.2. The CRCs and the URD shall take charge of the conduct of the proposal hearing.

6.3. The Researcher shall prepare a powerpoint presentation of the 
research proposal following the recommended format.

6.4. Each faculty researcher is given 10 minutes to present his/her proposal.

6.5. The panel members shall take turns in giving their comments and suggestions for the improvement of the research.

6.6. The researcher shall take note of the comments and suggestions of the panel and incorporate these into his/her research.

6.7. Researcher shall submit 3 soft-bound copies of their revised proposals two weeks after the proposal hearing.

7. Release of Tranche 1. The 1st financial assistance of P5,000.00 will be released after the proposal hearing. The requirements are: Standard Forms Number 2, 3 and 4; proposal hearing certification.

8. Release of Tranche 2. The 2nd financial assistance of P5,000.00 will be released after the researcher has revised the study based on the suggestions of the panel. The requirements are: Standard Forms Number 2 and 3; revised research proposal.

9. Release of Tranche 3. The 3rd financial assistance of P5,000.00 will be released after the submission of the final draft (which includes Chapter 2 and 3). The requirements are: Standard Forms Number 2 and 3; Five (5) copies of the final draft.

10. Oral Defense. Faculty Researcher is requested to present his/her findings and conclusion to a panel of experts (Chairman, Adviser, Members and Censor).

10.1. The CRCs and the URD shall take charge of the conduct of the oral defense.

10.2. The Researcher shall prepare a powerpoint presentation of the research proposal following the recommended format.

10.3. Each faculty researcher is given 10 minutes to present his/her research.

10.4. The panel members shall take turns in giving their comments and suggestions for the improvement of the research.

10.5. The researcher shall take note of the comments and suggestions of the panel and incorporate these into his/her research. 
11. Release of Tranche 4. The 4th financial assistance of P5,000.00 will be released after the oral defense. The requirements are: Standard Forms Number 2, 3 and 4; Oral defense certification.

12. University Research Forum and Certificate of Recognition. A certificate of recognition will be awarded to researcher during the University Research Forum where the researcher presents the findings and conclusion of his/her study to an audience.

13. Release of Tranche 5. The 5th financial assistance of P5,000.00 will be released after the researcher has incorporated all suggestions of referees for publication. The researcher receives $\mathrm{P} 4,000.00$ only (P1,000.00 to be paid to Censor). The requirements are: Standard Forms Number 2 and 3; three (3) hard-bound copies of research in black color with signed approval sheets; abstract (300 words); soft copy of research copied in CD-RW; certificate of recognition during University Research Forum; and research instruments.

14. Publication in the University Research Journal. The University Research Center (URC) shall publish all research projects in the University Research Journal. Researcher is requested to make a publishable article (5000 words). The publishable article shall have tables and figures (no more than 6) and references (no more than 40). External referees will be invited to review publishable article. Researcher is requested to revise publishable article based on the suggestions/comments of the referees. URC shall publish articles after suggestions/comments have been incorporated.

15. Publication in other journals. The researcher shall make a letter to the Chancellor noted by the CRC, CAD, URD and the Vice Chancellors for Academic Affairs, asking permission to submit publishable article to other journals (regional, national or international).

16. Oral or Poster Presentation in research conferences. In the same manner, the researcher shall make a letter to the Chancellor noted by the CRC, CAD, URD and the Vice Chancellors for Academic Affairs, asking permission to present research project (oral or poster presentation) in a regional, national or international research conference.

17. Sanctions for Non-compliance. If the researcher fails to submit the deliverables after the conduct of the University Research forum or decides to terminate the grant at any time, he/she will have to pay back the entire amount of the research grant through salary deduction.

Prepared by: Dr. Mauro Allan P. Amparado

Date of revision: June 1, 2013 


\section{UNIVERSITY OF CEBU \\ UNIVERSITY RESEARCH CENTER \\ STANDARD PROCEDURE NUMBER 2 \\ CONDUCT OF EXTERNALLY-FUNDED RESEARCH}

1. Prior to the application for external funding for research, the research team is to seek endorsement/approval from the Vice Chancellor for Academic Affairs through the University Research Director.

2. The research team shall develop their research proposals with the support of the University Research Center (URC) and the review and approval of such shall be done in accordance with university procedures for Institutional Faculty Research Grant.

3. Upon acceptance and approval of the research proposal/s by the externalfunding agency, the research team shall furnish a copy of all pertinent documents to the URC. All activities undertaken in line with the research shall be approved by proper authorities.

4. The URC shall monitor the progress of the research deliverables. The research team shall in turn update the URC on the progress of their research.

5. Upon completion of the research project, 3 copies of the research shall be submitted to URC. This becomes property of the URC.

6. A certificate of appreciation will be issued to the faculty researcher or research team, which shall be used as evidence for ranking purposes.

7. All research projects, oral presentations, poster presentations and published articles shall be made known to URC, otherwise, it will not be acknowledged for ranking purposes.

Prepared by: Dr. Mauro Allan P. Amparado

Date of revision: June 1, 2013 


\section{UNIVERSITY OF CEBU \\ UNIVERSITY RESEARCH CENTER \\ STANDARD PROCEDURE NUMBER 3 \\ RESEARCH METHODS AND THESIS WRITING}

\section{A. METHODS OF RESEARCH (1 ${ }^{\text {ST }}$ COURSE)}

1. The 1st Research subject in the curriculum (Research Methods) shall be under the supervision of the General Education Coordinator, in consultation with the College Dean/Chairperson and the Program Research Coordinator (PRC).

2. The instructor who shall teach Research Methods must be at least a master's degree holder (Thesis program).

3. The syllabus for Research must be aligned with all colleges in all the campuses of the university.

4. Only university-approved Research textbooks shall be used by the instructors.

5. The research outputs of the group of students (at most 5 students in a group) must only be research proposals.

6. No panel defense shall be conducted in any Research Methods class. Instead, proposal presentations are encouraged, the venue of which shall be inside the campus only. The presentation involves the instructor and the class only.

7. Collection of fees for whatever purpose is strictly prohibited.

8. Colors of the colleges are:

$\begin{array}{lll}\text { Arts } & - & \text { Violet } \\ \text { Business Administration } & - & \text { Red } \\ \text { Computer Studies } & - & \text { Light Blue } \\ \text { Criminology } & - & \text { Yellow } \\ \text { Customs Administration } & - & \text { Orange } \\ \text { Education } & - & \text { White } \\ \text { Engineering } & - & \text { Black } \\ \text { HRM } & - & \text { Brown } \\ \text { Law } & - & \text { Black } \\ \text { Marine Engineering } & - & \text { Dark Blue } \\ \text { Marine Transportation } & - & \text { Dark Blue } \\ \text { Nursing } & - & \text { Green }\end{array}$


9. Each group shall submit 3 hard-bound copies of their research proposals to the University Research Center (URC)/University Research Office (URO) before the end of the semester.

10. URC/URO shall create a masterlist and inventory of all completed proposals. All hard-bound copies will be endorsed to the University Library for public use.

\section{B. THESIS WRITING (2 $2^{\mathrm{ND}}$ COURSE)}

1. The 2nd Research subject in the curriculum (Thesis Writing) shall be under the supervision of the College Dean/Chairperson, in consultation with the Program Research Coordinator (PRC).

2. The instructor who shall teach Research Methods must be at least a master's degree holder (thesis program).

3. The syllabus for Thesis Writing must be aligned with all colleges in all the campuses of the university.

4. Only university-approved textbooks shall be used by the instructor.

5. The research outputs of the students must be in the form of a full-blown thesis.

6. Proposal hearing shall be done at the beginning of the semester, during the Prelim Grading Period. The group in the Research Methods class shall continue to be the same group in the Thesis Writing class. The 4 panel members are: 1 PRC (Chairman); 2 members; 1 adviser. The instructor of the class is the 2 nd member of the panel, but at no extra expense on the students.

7. An Oral Defense shall be conducted during the Final Grading Period. The panel members shall be the same members during the proposal hearing.

8. The group shall pay directly to cashier the following fees as deposit fund using Standard Form Number 10 - Honoraria of Research Panel. This deposit fund will be released by cashier to the panel at the end of the semester

Adviser - P500.00 per group (P200.00 for proposal defense during prelims/P300.00 final defense during semi-finals)

Chairman - P500.00 per group (P200.00 for proposal defense during prelims/P300.00 final defense during semi-finals)

Member 1 - P300.00 per group (P100.00 for proposal defense during prelims/P300.00 final defense during semi-finals) 
Member 2 - No payment (He/she is the instructor of the class)

Statistician - P500.00 per group

Censor - P500.00 per group

* Administrative fee of P200.00 per group

Total $\quad-\mathrm{P} 2,500.00$ per group

10. The group shall serve the research panel a modest provision of snacks (one liquid, one solid). No group shall serve lunch.

11. Instructors are requested to use Standard Form Number 5 (Proposal Hearing Rating Sheet) and Standard Form Number 6 (Oral Defense Rating Sheet) for grading research projects.

12. The College shall assign the date and venue for the Proposal Hearing and Oral Defense. Venues outside the campus are not allowed. Gift-giving by the students to the panel is discouraged.

13. Colors of the colleges are:

$\begin{array}{lll}\text { Arts } & - & \text { Violet } \\ \text { Business Administration } & - & \text { Red } \\ \text { Computer Studies } & - & \text { Light Blue } \\ \text { Criminology } & - & \text { Yellow } \\ \text { Customs Administration } & - & \text { Orange } \\ \text { Education } & - & \text { White } \\ \text { Engineering } & - & \text { Black } \\ \text { HRM } & - & \text { Brown } \\ \text { Law } & - & \text { Black } \\ \text { Marine Engineering } & - & \text { Dark Blue } \\ \text { Marine Transportation } & - & \text { Dark Blue } \\ \text { Nursing } & - & \text { Green }\end{array}$

14. Each group shall submit 3 hard-bound copies of their research proposals to the University Research Center (for Main)/University Research Office (for Banilad, METC and LM) before the end of the semester.

15. URC/URO shall create a masterlist and inventory of all completed proposals. All hard-bound copies will be endorsed to the University Library for public use.

Prepared by: Dr. Mauro Allan P. Amparado

Date of revision: June 1, 2013 
UNIVERSITY OF CEBU

UNIVERSITY RESEARCH CENTER

STANDARD FORM NUMBER 1

INSTITUTIONAL FACULTY RESEARCH GRANT APPLICATION FORM

Name of Researcher/s with Signature

1.

2.

Contact numbers:

Title of the Study:
Campus:

Department:

Date of Application:

Email Address:

\begin{tabular}{|l|c|c|}
\hline Rationale of the Study & Statement of the Problem & Methodology \\
\hline & & Budget \\
show breakdown) \\
\end{tabular}




\begin{tabular}{|l|l|l|l|}
\hline Rationale of the Study & Statement of the Problem & Methodology & Budget \\
\hline & & & \\
& & & \\
& & & \\
& & & \\
& & & \\
\end{tabular}




\begin{tabular}{|l|l|l|l|}
\hline Rationale of the Study & Statement of the Problem & Methodology & Budget \\
\hline & & & \\
& & & \\
& & & \\
& & & \\
& & & \\
\end{tabular}


(Sample Only)

Reviewed by:

Dr. Liza Lorena C. Jala

Dr. Mauro Allan P. Amparado

PRC, College of Education

University Research Director

Ms. Elna B. Sabornido

Dean, College of Education

Ms. Danielita B. Patindol

Campus Research Coordinator

Noted by:

Dr. Anna Liza B. Son

Campus Affairs Director

\section{Dr. Anna Liza B. Son}

Vice Chancellor for Academic Affairs

\section{Dr. Ulysses B. Aparece}

Vice Chancellor for Academic Affairs 


\section{UNIVERSITY OF CEBU \\ UNIVERSITY RESEARCH CENTER \\ STANDARD FORM NUMBER 2 \\ LETTER TO THE CHANCELLOR FOR THE \\ RELEASE OF TRANCHE}

Date:

Ms. Candice G. Gotianuy

Chancellor

University of Cebu

Cebu City

Thru: Dr. Helen C. Estrella, Executive Vice Chancellor for Operations

Engr. Anna Liza B. Son and Dr. Ulysses B. Aparece

Vice Chancellors for Academic Affairs

Dear Ms. Gotianuy:

Greetings!

The undersigned would like to apply for the release of Tranche of the Institutional Faculty Research. Attached herewith are the documents pertinent to this application.

Thank you.

Yours truly,

Signature over printed name

Employee ID Number

Title of Research:

College/Department:

Campus: 


\section{UNIVERSITY OF CEBU \\ UNIVERSITY RESEARCH CENTER \\ STANDARD FORM NUMBER 3 APPROVAL TO RELEASE TRANCHE}

1. Profile of the Researcher.

\begin{tabular}{|l|l|}
\hline Name of Applicant & \\
\hline Title & \\
\hline Employee ID Number & \\
\hline College/Department & \\
\hline Campus & \\
\hline
\end{tabular}

2. Please check applicable box and attach pertinent documents.

\begin{tabular}{|c|c|l|}
\hline Tranche & Amount & \multicolumn{1}{c|}{ Required Documents } \\
\hline$\square$ Tranche 1 & P5,000.00 & $*$ Standard Form Number 2 \\
& & $*$ Standard Form Number 3 \\
& & $*$ Standard Form Number 4 \\
& & $*$ Proposal Hearing Certification \\
\hline$\square$ Tranche 2 & P5,000.00 & $*$ Standard Form Number 2 \\
& & $*$ Standard Form Number 3 \\
& & $*$ Revised Research Proposal \\
\hline$\square$ Tranche 3 & P5,000.00 & $*$ Standard Form Number 2 \\
& & $*$ Standard Form Number 3 \\
& & $*$ Five copies of the final draft \\
\hline$\square$ Tranche 4 & P5,000.00 & $*$ Standard Form Number 2 \\
& & $*$ Standard Form Number 3 \\
& & $*$ Standard Form Number 4 \\
& & $*$ Oral Defense Certification \\
\hline$\square$ Tranche 5 & P5,000.00 & $*$ Standard Form Number 2 \\
& & $*$ Three Hard-bound copies in black color \\
& & $*$ Signed approval sheets and abstract for publication \\
& & $*$ Soft copy of research in CD-RW \\
& & $*$ Certificate of recognition \\
\hline
\end{tabular}

3. Route to approving signatories.

\begin{tabular}{|l|l|l|l|}
\hline & Signature & & Signature \\
\hline Researcher & & University Research & \\
& & Director & \\
\hline $\begin{array}{l}\text { Program Research } \\
\text { Coordinator }\end{array}$ & & VC for Academic & \\
\hline $\begin{array}{l}\text { Dean/ } \\
\text { Chairperson }\end{array}$ & Affairs & \\
\hline $\begin{array}{l}\text { Campus Research } \\
\text { Coordinator }\end{array}$ & & VC for Academic & \\
\hline
\end{tabular}

\section{Final Approval of the Chancellor.}


UNIVERSITY OF CEBU

UNIVERSITY RESEARCH CENTER

STANDARD FORM NUMBER 4

COMPLIANCE SHEET

Researcher:

Research Title:

Instruction: Please provide the researcher your comments and suggestions per research component.

\begin{tabular}{|l|}
\hline \multicolumn{1}{|c|}{ Research Components/Comments and Suggestions } \\
\hline Title \\
\hline Preliminary Pages \\
\hline Rationale \\
\hline Theoretical Background \\
\hline Statement of the Problem \\
\hline Significance of the Study \\
\hline Research Design and Research Flow \\
\hline
\end{tabular}




\begin{tabular}{|l|}
\hline \multicolumn{1}{|c|}{ Research Components/Comments and Suggestions } \\
\hline Research Environment \\
\hline Research Respondents/Subjects/Informants \\
\hline Research Instrument \\
\hline Gathering and Treatment of Data \\
\hline Definition of Terms \\
\hline Chapter 2 \\
\hline Proposed Output \\
\hline Chapter 3 \\
\hline
\end{tabular}

Name of Chairman/Member:

Signature and Date: 


\section{UNIVERSITY OF CEBU \\ UNIVERSITY RESEARCH CENTER \\ STANDARD FORM NUMBER 5 \\ PROPOSAL HEARING RATING SHEET}

Name of Researcher:

Title of Study:

College:

Date:

Instruction: Please check the box of the score per indicator, 20 as the highest score and 14 as lowest score. Take note that 15 is the passing score per indicator.

\begin{tabular}{|l|l|l|l|l|l|l|l|}
\hline \multicolumn{1}{|c|}{ Indicators } & $\mathbf{1 4}$ & $\mathbf{1 5}$ & $\mathbf{1 6}$ & $\mathbf{1 7}$ & $\mathbf{1 8}$ & $\mathbf{1 9}$ & $\mathbf{2 0}$ \\
\hline $\begin{array}{l}\text { Rationale and Theoretical } \\
\text { Background }\end{array}$ & & & & & & & \\
\hline $\begin{array}{l}\text { Statement of the Problem, } \\
\text { Statement of the Null } \\
\begin{array}{l}\text { Hypotheses and Significance } \\
\text { of the Study }\end{array}\end{array}$ & & & & & & & \\
\hline Research Methodology & & & & & & & \\
\hline Definition of Terms & & & & & & & \\
\hline $\begin{array}{l}\text { Preliminary Pages, References } \\
\text { and Appendices }\end{array}$ & & & & & & & \\
\hline
\end{tabular}

Total $=$

Grade $=$ (based on transmutation table of 100)

$\overline{\text { Name and Signature of Chairman/Member }}$ 


\section{UNIVERSITY OF CEBU \\ UNIVERSITY RESEARCH CENTER \\ STANDARD FORM NUMBER 6 \\ ORAL DEFENSE RATING SHEET}

Title of Study:

College:

Date:

Instruction: Please check the box of the score per indicator, 20 as the highest score and 14 as lowest score. Take note that 15 is the passing score per indicator.

\begin{tabular}{|l|l|l|l|l|l|l|l|}
\hline \multicolumn{1}{|c|}{ Indicators } & $\mathbf{1 4}$ & $\mathbf{1 5}$ & $\mathbf{1 6}$ & $\mathbf{1 7}$ & $\mathbf{1 8}$ & $\mathbf{1 9}$ & $\mathbf{2 0}$ \\
\hline Rationale and Theoretical & & & & & & & \\
Background & & & & & & & \\
\hline $\begin{array}{l}\text { Statement of the Problem, } \\
\text { Statement of the Null } \\
\text { Hypotheses and Significance of } \\
\text { the Study }\end{array}$ & & & & & & & \\
\hline $\begin{array}{l}\text { Research Methodology and } \\
\text { Definition of Terms }\end{array}$ & & & & & & & \\
\hline Findings and Implications & & & & & & & \\
\hline $\begin{array}{l}\text { Conclusion, Recommendations, } \\
\text { Output, References, } \\
\text { Appendices, Abstract and } \\
\text { Preliminary Pages }\end{array}$ & & & & & & & \\
\hline
\end{tabular}

Total $=$

Grade $=$ (based on transmutation table of 100)

$\overline{\text { Name and Signature of Chairman/Member }}$ 


\section{UNIVERSITY OF CEBU \\ UNIVERSITY RESEARCH CENTER \\ STANDARD FORM NUMBER 11 \\ HONORARIUM FOR CENSOR, INSTITUTIONAL FACULTY RESEARCH GRANT}

Name of Censor:

Honorarium: One Thousand Pesos Only (P1,000.00)

Name of Lead Researcher:

Campus:

Title of Research:

Prepared by:

Name and signature of Lead Researcher

Noted by:

$\overline{\text { Program Research Coordinator }} \quad \overline{\text { College Dean }}$

$\overline{\text { Campus Research Coordinator }} \quad \overline{\text { Campus Affairs Director }}$

Approved by:

Dr. Mauro Allan P. Amparado

University Research Director

Dr. Anna Liza B. Son and Dr. Ulysses B. Aparece

Vice Chancellors for Academic Affairs

Dr. Helen C. Estrella

Executive Vice Chancellor for Operations 
UNIVERSITY OF CEBU

UNIVERSITY RESEARCH CENTER

STANDARD FORM NUMBER 10

HONORARIUM FOR PANEL, UNDERGRADUATE THESIS

\begin{tabular}{|l|c|l|l|}
\hline \multicolumn{1}{|c|}{ Position } & Honoraria & Name & Conforme \\
\hline Adviser & P500.00 & & \\
\hline Chairman & P500.00 & & \\
\hline Member 1 & P500.00 & & \\
\hline Statistician & P800.00 & & \\
\hline Censor & P500.00 & & \\
\hline Administrative fee of P200.00 & \\
\hline
\end{tabular}

Name of Lead Researcher:

Department:

Campus:

Title of Research:

Prepared by:

Name and signature of Lead Researcher $\quad$ Research Class Instructor

Noted by:

Program Research Coordinator

Campus Research Coordinator

Approved by:

Dr. Mauro Allan P. Amparado

University Research Director

Dr. Anna Liza B. Son and Dr. Ulysses B. Aparece

Vice Chancellors for Academic Affairs

Dr. Helen C. Estrella

Eecutive Vice Chancellor for Academic Affairs
College Dean

Campus Affairs Director 

UNIVERSITY OF CEBU

UNIVERSITY RESEARCH CENTER

STANDARD FORM NUMBER 8

APPROVAL TO RELEASE PUBLICATION INCENTIVES

1. Profile of the Researcher

\begin{tabular}{|l|l|}
\hline Name of Applicant & (Last name, First Name and Middle Name) \\
\hline Employee ID Number & \\
\hline College/Department & \\
\hline Campus & \\
\hline Title of Researcher & \\
\hline $\begin{array}{l}\text { Name of Journal, Volume } \\
\text { number, Issue number, } \\
\text { year and ISSN number }\end{array}$ & \\
\hline
\end{tabular}

2. Please check applicable box and attach pertinent documents

\begin{tabular}{|l|l|l|}
\hline \multicolumn{1}{|c|}{ Tranche } & \multicolumn{1}{c|}{ Amount } & \multicolumn{1}{c|}{ Required Documents } \\
\hline $\begin{array}{l}\square \text { Article or abstract } \\
\text { published internationally }\end{array}$ & P5,000.00 & $\begin{array}{l}\text { *Standard Form Number } 8 \\
\text { *Photocopy of the article or abstract } \\
\text { *Photocopy of the journal cover }\end{array}$ \\
\hline $\begin{array}{l}\square \text { Article or abstract } \\
\text { published nationally }\end{array}$ & $\mathrm{P} 3,000.00$ & $\begin{array}{l}\text { *Standard Form Number } 8 \\
\text { *Photocopy of the article or abstract } \\
\text { *Photocopy of the journal cover }\end{array}$ \\
\hline
\end{tabular}

3. Route to approving signatories

\begin{tabular}{|l|l|l|l|}
\hline & Signatures & & Signatures \\
\hline Researcher & & $\begin{array}{l}\text { University Research } \\
\text { Director }\end{array}$ & \\
\hline $\begin{array}{l}\text { Program Research } \\
\text { Coordinator }\end{array}$ & & $\begin{array}{l}\text { VC for Academic } \\
\text { Affairs }\end{array}$ & \\
\hline Dean/ Chairperson & & $\begin{array}{l}\text { VC for Academic } \\
\text { Affairs }\end{array}$ & \\
\hline $\begin{array}{l}\text { Campus Research } \\
\text { Coordinator }\end{array}$ & & $\begin{array}{l}\text { Executive Director } \\
\text { for Operations }\end{array}$ & \\
\hline $\begin{array}{l}\text { Campus Affairs } \\
\text { Director }\end{array}$ & & & \\
\hline
\end{tabular}

4. Final Approval of the Chancellor

Ms. Candice G. Gotianuy

Chancellor 


\section{UNIVERSITY OF CEBU \\ UNIVERSITY RESEARCH CENTER \\ STANDARD FORM NUMBER 9 \\ RESEARCH FORUM EVALUATION}

$1^{\text {ST }}$ UC CLA RESEARCH FORUM

Direction: Please check the box corresponding to the number of your choice.

$\begin{array}{lll}5 & - & \text { Excellent } \\ 4 & - & \text { Very Good } \\ 3 & - & \text { Good } \\ 2 & - & \text { Fair } \\ 1 & - & \text { Poor }\end{array}$

\begin{tabular}{|l|l|l|l|l|l|}
\hline \multicolumn{1}{|c|}{ Indicators } & 1 & $\mathbf{2}$ & $\mathbf{3}$ & $\mathbf{4}$ & $\mathbf{5}$ \\
\hline 1. Registration is gracious and systematic. & & & & & \\
\hline 2. Program started and ended on time. & & & & & \\
\hline 3. Delivery of the Welcome Address. & & & & & \\
\hline 4. Introduction of the Board of Judges. & & & & & \\
\hline 5. Efficiency of the emcees. & & & & & \\
\hline 6. Organization and flow of the program. & & & & & \\
\hline 7. Venue is clean and well-arranged. & & & & & \\
\hline $\begin{array}{l}\text { 8. Venue is spacious and accommodates the } \\
\text { participants. }\end{array}$ & & & & & \\
\hline 9. Room temperature is comfortable. & & & & \\
\hline 10. Food served on time. & & & & \\
\hline 11. Food is palatable and nutritious. & & & & & \\
\hline $\begin{array}{l}\text { 12. Sound system is functional and enhances } \\
\text { the presentation of speakers. }\end{array}$ & & & & & \\
\hline 13. Dress code is followed. & & & & & \\
\hline 14. Presentable and informative invitations. & & & & & \\
\hline 15. Ushers are assistive and presentable. & & & & & \\
\hline
\end{tabular}

Comments and Suggestions 


\section{UNIVERSITY OF CEBU \\ UNIVERSITY RESEARCH CENTER \\ STANDARD FORM NUMBER 10 \\ DEPOSIT FUND FOR RESEARCH PANEL}

$1^{\text {ST }}$ UC CLA RESEARCH FORUM 


\title{
UNIVERSITY OF CEBU \\ UNIVERSITY RESEARCH CENTER \\ STANDARD TEMPLATE NUMBER 1 \\ TITLE PAGE
}

\section{EMPLOYABILITY OF THE UNIVERSITY OF CEBU GRADUATES FROM 1990 TO 2010}

\author{
(12 spaces) \\ An Institutional Faculty Research \\ Presented to the \\ University Research Center \\ University of Cebu
}

(12 spaces)

by

Crmgst. Elmira O. Negro, MSC

Faculty, College of Criminology

May 2011 


\section{UNIVERSITY OF CEBU \\ UNIVERSITY RESEARCH CENTER \\ STANDARD TEMPLATE NUMBER 2 \\ ABSTRACT}

The abstract is single spaced and no more than 300 words. It should be printed on one page only using Times New Roman 12, 13 or 14 .

The first paragraph of the abstract reflects the main problem and the proposed/enhanced output. It also presents the sub-problems in narrative form.

The 2nd paragraph is the methodology. It contains the following: research design (one sentence); number of respondents/subjects/informants (one sentence); sampling design (one sentence); research environment (one sentence); instrument (one sentence); and treatment of data (one sentence).

The 3rd paragraph presents the findings, conclusion and recommendations. The findings are direct answers to the sub-problems while the conclusion answers the main problem. The recommendations should be written in narrative form. 


\title{
UNIVERSITY OF CEBU \\ UNIVERSITY RESEARCH CENTER \\ STANDARD TEMPLATE NUMBER 3 \\ APPROVAL SHEET
}

This faculty research entitled "Students' Entrepreneurship in the College of Business Administration and Accountancy" prepared and submitted by Reah G. Fabrica and Eric P. Gabutin of the College of Business Administration and Accountancy, University of Cebu - Main has been examined, accepted and approved.

\section{PANEL OF EXAMINERS}

Mauro Allan P. Amparado, Ph.D.

Chairman

\author{
Rosielyn D. Tan, Ed.D. \\ Anna Katrina O. Watin, M.A. \\ Censor \\ Member \\ Gilda N. Salvo, M.A. \\ Danielita D. Patindol, M.A. \\ Member \\ Member
}

Marcial T. Chiu, M.A.

Censor

Mauro Allan P. Amparado, Ph.D.

Chairman

Engr. Anna Liza B. Son, MSManE

Vice Chancellor for Academic Affairs
Ulysses B. Aparece, Ph.D.

Vice Chancellor for Academic Affairs

Date: May 31, 2011 


\section{UNIVERSITY OF CEBU UNIVERSITY RESEARCH CENTER \\ STANDARD TEMPLATE NUMBER 4 RESEARCH STYLE GUIDELINES}

1. All written outputs should be printed on short bond papers.

2. Use Times New Roman as font style, size 14, and double-spacing for all entries, except abstract.

3. Margins of the bond paper are 1.5 " left, and 1.0 inch for the top, bottom and right margins.

4. Pagination should be on the upper right hand corner of the page. No page number should appear on the $1^{\text {st }}$ page.

5. Title contains the following:

- Independent and dependent variables.

- Output can be included; separate this with a colon mark (optional).

- Bold letters and capitalized.

- Written like an inverted pyramid.

- No waste words (such as A, An, The, Basis for).

- Reflects the name of the researcher/researchers and the month and year of oral defense.

\section{Approval Sheet.}

- For undergraduate and graduate thesis, approval sheet duly signed by the Panel of Examiners, Program Research Coordinator, Campus Research Coordinator and Dean.

- For Faculty Research, approval sheet duly signed by the Panel of Examiners, Campus Research Coordinator and University Research Director.

7. Table of Contents.

- List down content and page in Arabic numbers.

- Acknowledgment and Abstract in Roman numbers.

- Separate sheet for List of tables and figures.

8. Abstract contains the following:

- The Problem (Statement of the Problem and Statement of the Null hypothesis).

- Research Methodology

- Findings

- Conclusion

- Recommendations

- Should be stated in simple past tense and third person. 
9. Rationale mentions the following:

- A striking statement or a general knowledge about the topic.

- What has been done before and how the study differs.

- Statistics or prevailing situationer.

- Researcher's competency.

- No lifting of statements from references except for the first paragraph.

10. Theoretical Background states the following:

- Main theory to which the study is anchored.

- Supporting theories used.

- Literature on the variables of the study.

- Local, national, and international studies.

- Proper parenthetical citations.

- Correct grammar and composition.

- No one-sentence paragraph.

- May show the original theoretical model.

11. Statement of the Problem (for quantitative studies) or Objectives of the Study (for experimental studies and qualitative studies).

- State the main and specific problems.

- State the possibility for a significant difference and/or significant relationship among variables.

12. Statement of the Null Hypothesis.

- Congruent with the specific problems.

- Variables are identified.

13. Significance of the Study explains who will be the beneficiaries of the study and how they will benefit/gain.

14. Research Methodology starts with the Research Design which explains the type of design used in relation to the main problem. Show the figure of the Flow of the Study (Input-Process-Output).

15. Research Environment describes the setting of the study.

16. Research Subjects/Respondents/Informants

- Describes the total population, sampling method used, sampling size determination, and characteristics of the sample.

- Use the term research subjects if it is an experimental study.

- Use the term research respondents if they are answering a tool.

- Use the term research informants if they are interviewed.

- Use the term participants if there are subjects and respondents in the study. 
17. Research Instrument describes the tool/questionnaire/interview guide utilized.

18. Research Procedures include the Gathering of Data and Treatment of Data.

- For the Gathering of Data, discuss step by step how data was gathered starting from the approval of the study by the institution until the retrieval of the instrument from respondents.

- For the Treatment of Data, enumerate and describe the statistical tools used. No need to show the formula.

- State if data was manually computed or has used a statistical software.

- For qualitative data, describe how the answers of the informants during the interview were collapsed into themes.

19. Definition of Terms.

- Alphabetically arranged.

- Operationally defined or how terms were used in the study.

- Taken from the title, main problem and specific problems.

20. Presentation, Interpretation and Analysis of the Study contains:

- Detailed findings consistent with the specific problems.

- Findings should have implications lifted from the theoretical background. Include the parenthetical citation.

- Table should precede the description of the table.

- Do not cut tables.

- Sequence of tables is congruent to the sequence of specific problems.

- No graphs and pictures.

21. Summary, Findings, Conclusion and Recommendations.

- For the summary, copy the main and specific problems. Explain the methodology in 1-2 paragraphs.

- Findings show the most dominant information per sub-problem.

- Conclusion answers the main problem.

- Recommendations are made by the researcher based on findings of the study.

22. Output of the Study.

- Placed one page after the recommendations.

- Can be an action plan or those that can be immediately implemented such as seminars, brochures and manuals.

23. References.

- Absolutely no internet sources.

- List down alphabetically with the following sub-headings: 
- Books

- Journals

- Unpublished Theses and Dissertations

- Other sources

- Correct format.

- Copyright from 2000 to present.

- At least 30 sources from books, journals, theses, dissertations and other sources.

- Consistent use of APA (American Psychological Association) format.

\section{Appendices.}

- A for transmittal letters (to persons and institutions).

- B for tool/interview guide.

- C is map of research environment map.

- D is for others (e.g. MOA)

- $\mathrm{E}$ is the curriculum vitae of the researcher.

25. Curriculum Vitae.

- Contains the educational attainment (highlights highest educational attainment).

- Work experience if applicable.

- Personal data of the researcher.

- With 2x2 picture on the right upper hand corner; may be scanned.

- Contact information like email address, home address and mobile numbers.

26. Please prepare 5 copies during the final defense and fasten each copy in a short folder. Submit the copy to the panelist at least 1 week before the defense date. This will give him/her time to evaluate the manuscript.

27. Approval sheet should be completely signed by panelists before final binding (hard-bound). This means that all corrections/suggestions should be accomplished before final binding.

28. Respect the chain of command. Censor will evaluate first, then the panel members, and then the chairman of the panel. The Dean/Chairperson/Research Director should be the last person to sign.

29. Submit the 5 hard bound copies to the research teacher for grading. Submit also 1 CD (CD Writeable) with the soft copy of the entire manuscript.

30. Research teachers are requested to submit the 5 hard bound copies and $\mathrm{CD}$ to the University Research Center. 


\section{UNIVERSITY OF CEBU \\ UNIVERSITY RESEARCH CENTER \\ STANDARD TEMPLATE NUMBER 5 \\ TABLE OF CONTENTS}

\section{PRELIMINARY PAGES}

Title Page $\quad$ i

Approval Sheet

Abstract iii

Table of Contents iv

List of Figures $\quad$ V

List of Tables $\quad \mathrm{x}$

CHAPTER 1

THE PROBLEM AND ITS SCOPE

INTRODUCTION

Rationale 1

Theoretical Background $\quad 5$

THE PROBLEM 45

Statement of the Problem (or Objectives of the Study) 45

Statement of the Null Hypothesis $\quad 46$

$\begin{array}{ll}\text { Significance of the Study } & 47\end{array}$

RESEARCH METHODOLOGY 50

$\begin{array}{ll}\text { Research Environment } & 50\end{array}$

Research Subjects or Respondents $\quad 51$

Research Instrument $\quad 52$

Research Procedure $\quad 53$ 
Gathering of Data $\quad 53$

Treatment of Data $\quad 54$

DEFINITION OF TERMS

CHAPTER 2

PRESENTATION, ANALYSIS AND

INTERPRETATION OF DATA

CHAPTER 3

SUMMARY, FINDINGS, CONCLUSION AND

RECOMMENDATIONS

$\begin{array}{ll}\text { Summary } & 101\end{array}$

$\begin{array}{ll}\text { Findings } & 103\end{array}$

$\begin{array}{ll}\text { Conclusion } & 105\end{array}$

$\begin{array}{ll}\text { Recommendations } & 106\end{array}$

PROPOSED OR ENHANCED OUTPUT 107

REFERENCES 115

$\begin{array}{ll}\text { Books } & 116\end{array}$

$\begin{array}{ll}\text { Journals } & 117\end{array}$

$\begin{array}{ll}\text { Unpublished Theses and Dissertations } & 118\end{array}$

APPENDIX A

TRANSMITTAL LETTER 119

APPENDIX B

RESEARCH INSTRUMENT 120

APPENDIX C

RESEARCH ENVIRONMENT MAP 121

APPENDIX D

MEMORANDUM OF AGREEMENT 
TABLE OF CONTENTS (FOR COMPUTER STUDIES)

\section{PRELIMINARY PAGES}

Title Page $\quad$ i

Names of Researchers ii

Approval Sheet $\quad$ iii

Acknowledgement iv

Abstract $\quad$ v

List of Figures

List of Tables $\quad \mathrm{x}$

CHAPTER 1

THE PROBLEM AND ITS SCOPE

INTRODUCTION 1

Rationale of the Study 1

Theoretical Background 5

THE PROBLEM 45

Statement of the Problem 45

Statement of the Null Hypothesis (optional) 46

$\begin{array}{ll}\text { Significance of the Study } & 47\end{array}$

CHAPTER 2

PRESENTATION, ANALYSIS AND

INTERPRETATION OF DATA 48

Presentation, Analysis and Interpretation of Data 48

Proposed Development

Requirement Analysis

Functional Requirements

Non-functional Requirements 
Usability Requirements

Models

Design of Prototype

Design of System

Implementation View of the System

Cost and Benefit Analysis 


\section{UNIVERSITY OF CEBU \\ UNIVERSITY RESEARCH CENTER}

\section{JOB DESCRIPTION OF THE CAMPUS RESEARCH COORDINATOR}

Reports to: University Research Director

Coordinates with: Campus Affairs Director, University Research Director, Deans, Chairs, Principals and Program Research Coordinators

- Participates in research planning and evaluation of the program.

- Allocates research budget of the campus in different research activities.

- Oversees research activities of faculty and students in the campus.

- Monitors the activities of Research Instructors in the campus.

- Monitors the faculty and students' research presentations and publications.

- Guides faculty and students on the entire research process from problem identification to dissemination of findings.

- Oversees procurement of supplies and equipment.

- Performs other research tasks as directed by University Research Director, Campus Affairs Director and Deans.

\section{JOB DESCRIPTION OF THE PROGRAM RESEARCH COORDINATOR}

Reports to: Campus Research Coordinator

Coordinates with: Deans, Chairs, Principals, Faculty and Students

- Participates in research planning and evaluation of the program.

- Approves proposals and research outputs of faculty and students.

- Act as chairman of the panel during thesis oral defense.

- Collates and submits the lists of researches in coordination with research instructors every end of the semester.

- Oversees procurement supplies and equipment in the program.

- Attend regular meeting as requested by the campus research coordinator and University Research Director.

- Oversees research activities of faculty and students in the program such as research fora, lectures and workshops.

- Performs other research tasks as directed by the Campus Research Coordinator and Dean. 


\section{UNIVERSITY OF CEBU \\ UNIVERSITY RESEARCH CENTER \\ INSTITUTIONAL FACULTY RESEARCHES \\ PUBLISHED IN NOVUS RESEARCH JOURNAL \\ ISSN 2094-0793}

\section{VOLUME 1, SY 2006-2007}

- The Potentials in Increasing Philippine-Indonesia Relations: The Subject of Trade by Mr. Hans Christian Tesch.

- Co-curricular and Extra-curricular Activities in the College of Education by Ms. Liza Chua-Hardel.

- Development of a Client- Based Training Program for Banking and Finance Students by Ms. Ma. Fe Planco-Imbong.

- Shifts in the Accountancy Curriculum by Ms. Ma. Rosalina AraraoBesario.

- The Design and the Development of an On- Line Assessment by Chere B. Velasquez and Engr. Mark Nacua.

- Profile of Customs Graduates Employed in Customs Brokerage and Forwarding Firms in the Port of Cebu: Basis for On-line Profiling by Mr. Giovanni C. Basilgo.

- Nonsensical Rhymes in Cebuano by Dr. Alma V. Jaguros.

\section{VOLUME 2,}

- Performance in UC Graduates in the 2004 Licensure Examinations for Teachers (LET) Implication to Education by Dr. Alma V. Jaguros.

- Level of Communications Skills of UC Applicants: Implication to Employability in Cebu- Based Contact Centers by Kathleen N. Abasolo.

- Perceptions of the Students on Faculty Efficiency of the Marine Engineering Department by Gilbert L. Legaspi.

- Vocabulary profile of Tile Bachelor of Arts Freshmen Students of the University of Cebu by Araceli Beltran.

- Oral Communication Problems of Student in the College of Education Enrolled in English 3, First Semester 2005-2006 by Miriam Mahusay. 


\section{VOLUME 3}

A Survey on the Types of Learners from the Skeletal Colleges of the University of Cebu $2^{\text {nd }}$ Semester School Year 2006- 2007 by Emily Jean A. Gonzales, October 2007

Criminology Students' Perception of Laboratory Activities: Basis for Improvement by Atty. Gil Toledo Pabilona, October 2007

University of Cebu Integrated Library System (UC- ILS) Prototype by Lea Caballero, October 2007

An Online Grading System for the College Of Information and Computer Science of the University of Cebu by Eduardo Espiritu, October 2007

Rigalu: The Ritual of Gift Giving Among the Sukdan Shamans of Northern Bohol: A Study in Anthropological Ethics and Poetry by Dr. Ulysses B. Aparecee, October 2007

The Professional Preparation and Practices of the Grade School Teachers of the University of Cebu in Relation to their Teaching Effectiveness by Dr. Glenn R. Andrin, October 2007

\section{VOLUME 4, SY 2009-2010}

- Ferrocement Production: A Low- Cost Housing Technology by Engr. Raymundo Barros Absin.

- Report On Alumni Tracer Study Programme By Dr. Erlinda P. Barcelo.

- Values Reflections On Children's Literary Verses by Dr. Glenn R. Andrin.

- Lunas: The "Mother" Of All Sukdan Shaman's Curing Rituals by Dr. Ulysses B. Aparece.

- Tracer Study of the UC Graduate School by Dr. Alicia J. Tan. 


\section{UNIVERSITY OF CEBU \\ UNIVERSITY RESEARCH CENTER \\ INSTITUTIONAL FACULTY RESEARCHES \\ SY 2010-2011}

Factors Related to the Maritime Pre-apprenticeship Phase: A Proposed Maritime Pre-apprenticeship Program by Maria Salud M. De Los Santos.

2010 Graduate Tracer Study, University of Cebu-Main by Dr. Maria Salud M. De Los Santos.

University of Cebu, Graduate Tracer Study 2005-2010 by Maria Salud Medida-de los Santos, PhD

Success Factors of Student Achievers of the University of Cebu by Ms. Araceli Beltran

The Performance Level of Banking \& Finance Office Practice Trainees: Basis for the Modification of the Program by Ma. Fe Planco-Imbong, M.P.A.

The University of Cebu College of Commerce Accountancy Students Organizations by Ma. Fe Planco-Imbong

The 2010 OJT of the College of HRM by Renato C. Sagayno, Dev. Ed. D. and Mr. Ernesto Labra Jr.

The UC CWTS / CESDEV Program in Sapangdaku, Guadalupe, Cebu City, SY 2007-2009 by Nelson Aldrich L. Esguerra

Small Medium Enterprise of UC Commerce Stakeholders: Problems Encountered and Sustainability by Ms. Reah Fabrica and Mr. Eric Gabutin

Information Technology: Its Impact on Seafarers by Engr. Marlk N. Abadiano

The Effectiveness of University of Cebu, College Education Teacher's Board Review Program by Ms. Windey Prado and Ms. Quennie Ypanto

Employability of University of Cebu Criminology Graduates (SY 20042009) by Esmeraldo E. Damuag

Employability of Marine Engineering (Non-Scholars) Graduates of UCMaritime Education 2009-2011 by Ms. Minette Abagon and Mr. Mark N. Abadiano 
Customer Satisfaction of the Student Personnel Services in Marine Transportation Department by Mr. Pacienciano Punay and Mr. Regilito Sanchez

Utilization of Bridge Simulator and Computer Laboratories for Computerbased Training Programs in the Marine Transportation Department by Mr. Lester U. Wee and Mr. Collin Gesto

Online Student-based Faculty Evaluation System of University of CebuMain by Mr. Dennis S. Durano and Ms. Jennifer G. Amores

Philosophical Concepts of Education and Teaching Performance Profile by Mr. Cesar P. Gulang and Ms. Meriam Mahusay

Research Capability of the Faculty University of Cebu-Main by Renato C. Sagayno and Steven Y. Razonable

Students' Awareness on the Student Manual by Ms. Kathryn Marie T. Monterroyo and Ms. Therirose Ann B. Tan

Jigsaw Strategy in Teaching and Learning Philippine History by Cherry G. Tandiado and Jasmin V. Bonghanoy

Tracer Study on the UC-Banilad Graduates 2005-2010 by Mr. Danilo Olaer and Ms. Elizabeth Mendoza

Integration of Information and Communications Technology to Instruction by Ms. Jonnette B. Labrador and Mr. Edsel Paray

University of Cebu-Banilad Library Services and Utilization by Ms. Judy Ann Ferrater and Ms. Roselita Doming

Evaluation of the UC-Banilad Community Extension Services and Development by Ms. Jocelyn Lim and Ms. Helen Mae Pogoy 


\section{UNIVERSITY OF CEBU \\ UNIVERSITY RESEARCH CENTER}

FOLDER A

URC MANUAL SY 2011-2012, ISSN 2243-7568

TABLE OF CONTENTS

\begin{tabular}{|l|c|}
\hline \multicolumn{1}{|c|}{ CONTENT } & PAGE \\
\hline Vision, Mission, Institutional Goals & 1 \\
\hline Core Values and University of Cebu Hymn & 2 \\
\hline URC Departmental Objectives & 3 \\
\hline URC Personnel & 3 \\
\hline Organizational Structure & 5 \\
\hline $\begin{array}{l}\text { Research Agenda for Institutional Faculty Research } \\
\text { SY 2011-2012 }\end{array}$ & 7 \\
\hline $\begin{array}{l}\text { Departmental Agenda for SY 2011-2012 to } \\
\text { SY 2015-2016 }\end{array}$ & 10 \\
\hline $\begin{array}{l}\text { Central Visayas - Regional Development Research } \\
\text { Agenda, 2009-2015 }\end{array}$ & 20 \\
\hline $\begin{array}{l}\text { Standard Procedure Number 1, Institutional Faculty } \\
\text { Research Grant }\end{array}$ & 23 \\
\hline $\begin{array}{l}\text { Standard Procedure Number 2, Conduct of Externally- } \\
\text { funded Research }\end{array}$ & 24 \\
\hline $\begin{array}{l}\text { Standard Procedure Number 3, Research Methods and } \\
\text { Thesis Writing }\end{array}$ & 27 \\
\hline $\begin{array}{l}\text { Standard Form Number 1, Institutional Faculty } \\
\text { Research Grant Application Form }\end{array}$ & 30 \\
\hline $\begin{array}{l}\text { Standard Form Number 2, Letter to the Chancellor for } \\
\text { the Release of Tranche }\end{array}$ & 31 \\
\hline $\begin{array}{l}\text { Standard Form Number 3, Approval to Release } \\
\text { Tranche }\end{array}$ & 32 \\
\hline Standard Form Number 4, Compliance Sheet & 34 \\
\hline $\begin{array}{l}\text { Standard Form Number 5, Proposal Hearing Rating } \\
\text { Sheet }\end{array}$ & 38 \\
\hline Standard Form Number 6, Oral Defense Rating Sheet & 35 \\
\hline $\begin{array}{l}\text { Standard Form Number 7, Honorarium for Censor and } \\
\text { External Member }\end{array}$ & 36 \\
\hline Standard Template Number 1, Title Page \\
\hline Standard Template Number 2, Abstract \\
\hline Standard Template Number 3, Approval Sheet \\
\hline $\begin{array}{l}\text { Standard Template Number 4, Research Style } \\
\text { Guidelines }\end{array}$ & 39 \\
\hline Standard Template Number 5, Table of Contents \\
\hline
\end{tabular}




\title{
UNIVERSITY OF CEBU \\ UNIVERSITY RESEARCH CENTER
}

\author{
FOLDER B \\ URC MEMOS AND LETTERS SY 2011-2012
}

TABLE OF CONTENTS

\begin{tabular}{|l|c|}
\hline \multicolumn{1}{|c|}{ CONTENT } & PAGE \\
\hline $\begin{array}{l}\text { Memo Number 1, 2011 In-service Training for } \\
\text { Research }\end{array}$ & 2 \\
\hline $\begin{array}{l}\text { Memo Number 2, Seminar on Conceptualizing } \\
\text { Research Problems }\end{array}$ & 3 \\
\hline $\begin{array}{l}\text { Memo Number 3, Requirements for the Release of } \\
\text { Tranche 5, 2010 Institutional Faculty Research }\end{array}$ & 4 \\
\hline $\begin{array}{l}\text { Memo Number 4, 2011 Institutional Faculty Research } \\
\text { Grant }\end{array}$ & 9 \\
\hline $\begin{array}{l}\text { Memo Number 5, Identification of Program Research } \\
\text { Coordinators SY 2011-2012 Call for Papers, 4 } \\
\text { Taiwan-Philippines Academic Confab }\end{array}$ & \\
\hline $\begin{array}{l}\text { Memo Number 6,University of San Carlos Research } \\
\text { Project 2011 }\end{array}$ & 20 \\
\hline $\begin{array}{l}\text { Memo Number 7, Asian Public Intellectuals (API) } \\
\text { Research Grant 2012-2013 }\end{array}$ & 21 \\
\hline $\begin{array}{l}\text { Memo Number 8, Orientation on Asian Public } \\
\text { Intellectuals Research Grant Formulation of the } \\
\text { Program Research Agenda }\end{array}$ & 26 \\
\hline $\begin{array}{l}\text { Memo Number 9, Proposal Hearing and Oral Defense } \\
\text { Rating Sheets }\end{array}$ & 27 \\
\hline $\begin{array}{l}\text { Memo Number 10, Approved UC Research Scheme } \\
\text { for API; 2nd Cebu International TESOL Conference }\end{array}$ & 30 \\
\hline $\begin{array}{l}\text { Memo Number 11, Meeting for PACUCOA Best Case } \\
\text { Study Competition }\end{array}$ & 42 \\
\hline $\begin{array}{l}\text { Memo Number 12, Approved 2011 Institutional } \\
\text { Faculty Research Projects (1 }\end{array}$ & 57 Batch of Research \\
Projects) & 53 \\
\hline Memo Number 13, USC Research Forum & 50 \\
\hline $\begin{array}{l}\text { Memo Number 14, Standard Procedure Number 2 and } \\
\text { 3; Seminar on Validating Researcher-made Instruments }\end{array}$ & 57 \\
\hline $\begin{array}{l}\text { Memo Number 15, Schedule of 2011 Institutional } \\
\text { Faculty Research Proposal Hearing }\end{array}$ & \\
\hline $\begin{array}{l}\text { Memo Number 16, Call for Abstracts, World Research } \\
\text { Festival 2012 }\end{array}$ & 59 \\
\hline $\begin{array}{l}\text { Memo Number 17, Formulation of URC Development } \\
\text { Plan for 2011-2014 }\end{array}$ & \\
\hline
\end{tabular}





\title{
UNIVERSITY OF CEBU \\ UNIVERSITY RESEARCH CENTER
}

\author{
FOLDER C \\ INSTITUTIONAL FACULTY RESEARCH GRANTS
}

TABLE OF CONTENTS

\begin{tabular}{|l|c|}
\hline \multicolumn{1}{|c|}{ CONTENT } & PAGE \\
\hline $\begin{array}{l}\text { Memorandum of Agreement for 2011 Institutional } \\
\text { Faculty Research, Mr. Cesar P. Gulang and Ms. } \\
\text { Meriam G. Mahusay }\end{array}$ & \\
\hline $\begin{array}{l}\text { Memorandum of Agreement for 2011 Institutional } \\
\text { Faculty Research, Dr. Renato C. Sagayno and Mr. } \\
\text { Steven Y. Razonable }\end{array}$ & 2 \\
\hline $\begin{array}{l}\text { Memorandum of Agreement for 2011 Institutional } \\
\text { Faculty Research, Mr. Dennis S. Durano and Ms. } \\
\text { Jennifer G. Amores }\end{array}$ & 3 \\
\hline $\begin{array}{l}\text { Memorandum of Agreement for 2011 Institutional } \\
\text { Faculty Research, Ms. Minette O. Abagon and Mr. } \\
\text { Mark N. Abadiano }\end{array}$ & 4 \\
\hline $\begin{array}{l}\text { Memorandum of Agreement for 2011 Institutional } \\
\text { Faculty Research, Ms. Jonnette B. Labrador and Mr. } \\
\text { Edsel C. Paray }\end{array}$ & 5 \\
\hline $\begin{array}{l}\text { Memorandum of Agreement for 2011 Institutional } \\
\text { Faculty Research, Ms. Judy Ann O. Ferrater and Ms. } \\
\text { Roselita R. Doming }\end{array}$ & 6 \\
\hline $\begin{array}{l}\text { Memorandum of Agreement for 2011 Institutional } \\
\text { Faculty Research, Mr. Danilo C. Olaer Jr. and Ms. } \\
\text { Elizabeth C. Mendoza }\end{array}$ & 7 \\
\hline $\begin{array}{l}\text { Memorandum of Agreement for 2011 Institutional } \\
\text { Faculty Research, Ms. Jocelyn A. Lim and Ms. Helen } \\
\text { Mae O. Pogoy }\end{array}$ & 8 \\
\hline $\begin{array}{l}\text { Memorandum of Agreement for 2011 Institutional } \\
\text { Faculty Research, Ms. Cherry G. Tantiado and Jasmin } \\
\text { V. Bonghanoy }\end{array}$ & \\
\hline $\begin{array}{l}\text { Memorandum of Agreement for 2011 Institutional } \\
\text { Faculty Research, Ms. Kathryn Marie T. Monterroyo } \\
\text { and Ms. Therirose Anne B. Tan }\end{array}$ & 10 \\
\hline $\begin{array}{l}\text { Application Form, Mr. Cesar P. Gulang and Ms. } \\
\text { Meriam G. Mahusay }\end{array}$ & 11 \\
\hline $\begin{array}{l}\text { Application Form, Dr. Renato C. Sagayno and Mr. } \\
\text { Steven Y. Razonable }\end{array}$ & 12 \\
\hline $\begin{array}{l}\text { Application Form, Mr. Dennis S. Durano and Ms. } \\
\text { Jennifer G. Amores }\end{array}$ & 13 \\
\hline $\begin{array}{l}\text { Application Form, Ms. Minette O. Abagon and Mr. } \\
\text { Mark N. Abadiano }\end{array}$ & 14 \\
\hline
\end{tabular}




\begin{tabular}{|l|c|}
\hline \multicolumn{1}{|c|}{ CONTENT } & PAGE \\
\hline $\begin{array}{l}\text { Application Form, Ms. Jonnette B. Labrador and Mr. } \\
\text { Edsel C. Paray }\end{array}$ & 15 \\
\hline $\begin{array}{l}\text { Application Form, Ms. Judy Ann O. Ferrater and Ms. } \\
\text { Roselita R. Doming }\end{array}$ & 16 \\
\hline $\begin{array}{l}\text { Application Form, Mr. Danilo C. Olaer Jr. and Ms. } \\
\text { Elizabeth C. Mendoza }\end{array}$ & 17 \\
\hline $\begin{array}{l}\text { Application Form, Ms. Jocelyn A. Lim and Ms. Helen } \\
\text { Mae O. Pogoy }\end{array}$ & 18 \\
\hline $\begin{array}{l}\text { Application Form, Ms. Cherry G. Tantiado and Jasmin } \\
\text { V. Bonghanoy }\end{array}$ & 19 \\
\hline
\end{tabular}




\section{UNIVERSITY OF CEBU \\ UNIVERSITY RESEARCH CENTER}

\section{FOLDER E \\ RESEARCHES ACCEPTED FOR POSTER PRESENTATION, ORAL PRESENTATION, PUBLICATION AND AWARDS}

TABLE OF CONTENTS

\begin{tabular}{|c|c|}
\hline CONTENT & \multirow[t]{2}{*}{ PAGE } \\
\hline $\begin{array}{l}\text { RESEARCHES ACCEPTED FOR POSTER } \\
\text { PRESENTATION AND ORAL PRESENTATION }\end{array}$ & \\
\hline SY 2011-2012 & 1 \\
\hline $\begin{array}{l}\text { The First Year Education Students' Learning Style and } \\
\text { their Academic Performance by Ms. Moonyen O. } \\
\text { Tecson and Ms. Elna B. Sabornido. }\end{array}$ & \\
\hline $\begin{array}{l}\text { Presentor, } 2^{\text {nd }} \text { Internationalization of Higher Education } \\
\text { Research Conference, October } 21 \text { and 22, 2011, } \\
\text { Bacolod City, Philippines. }\end{array}$ & \\
\hline $\begin{array}{l}\text { Jigsaw Strategy in Teaching and Learning Philippine } \\
\text { History and Constitution by Ms. Cherry G. Tantiado. }\end{array}$ & 2 \\
\hline $\begin{array}{l}\text { Presentor, } 2^{\text {nd }} \text { Internationalization of Higher Education } \\
\text { Research Conference, October } 21 \text { and 22, 2011, } \\
\text { Bacolod City, Philippines. }\end{array}$ & \\
\hline $\begin{array}{l}\text { UC-METC's Shipboard Maritime Apprenticeship as a } \\
\text { Cadet-centered Mechanism towards Environmental } \\
\text { Pollution Abatement by Mr. Noel P. Crucio, Capt. } \\
\text { Arnel N. Malaga, Mr. Alberto C. Felisilda Jr. and Mr. } \\
\text { Robert M. Maluya. }\end{array}$ & 3 \\
\hline $\begin{array}{l}\text { Presentor, } 2^{\text {nd }} \text { Internationalization of Higher Education } \\
\text { Research Conference, October } 21 \text { and 22, 2011, } \\
\text { Bacolod City, Philippines. }\end{array}$ & \\
\hline $\begin{array}{l}\text { Students' Entrepreneurship in the College of Business } \\
\text { Administration and Accountancy, University of Cebu } \\
\text { Main Campus by Ms. Rhea G. Fabrica and Mr. Eric P. } \\
\text { Gabutin. }\end{array}$ & 5 \\
\hline 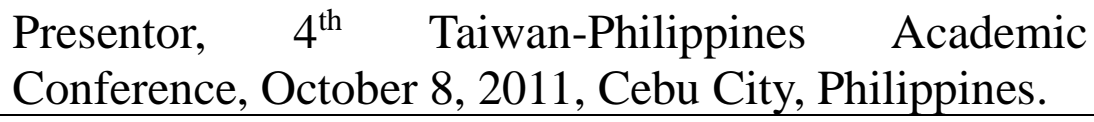 & \\
\hline $\begin{array}{l}\text { Motivation and Research Capability of the University } \\
\text { of Cebu Faculty by Dr. Rosielyn D. Tan. }\end{array}$ & 9 \\
\hline $\begin{array}{l}\text { Accepted paper for the } 15^{\text {th }} \text { East Asian Forum of } \\
\text { Nursing Scholars Conference, February } 22-23,2012 \text {, }\end{array}$ & \\
\hline
\end{tabular}




\begin{tabular}{|c|c|}
\hline CONTENT & PAGE \\
\hline Singapore. & \\
\hline $\begin{array}{l}\text { Implementation of Dengue Control Measures in the } \\
\text { City of Naga, Cebu, Philippines by Mr. Francis Rufo } \\
\text { and Dr. Mauro Allan P. Amparado. } \\
\text { Accepted paper for the Asia-Pacific Research } \\
\text { Symposium (APRS), February 24, 2012, Singapore. }\end{array}$ & 10 \\
\hline $\begin{array}{l}\text { Factors Related to the Maritime Pre-apprenticeship } \\
\text { Phase: A Proposed Maritime Pre-apprenticeship } \\
\text { Program by Dr. Maria Salud M. De Los Santos, Dr. } \\
\text { Glenn R. Andrin, Mr. Alberto C. Felisilda Jr., Dr. Ily E. } \\
\text { Abella and Dr. Nelson Esguerra. } \\
\text { Oral Presentation, CHED-GIA 2009 Network } \\
\text { Research Project Presentation, August 20, 2010, Cebu } \\
\text { City, Philippines. }\end{array}$ & 11 \\
\hline $\begin{array}{l}\text { Construction Equipment Selection Using Analytic } \\
\text { Hierarchy Process (AHP) by Engr. Benedict B. } \\
\text { Banquil. } \\
\text { Oral Presentation, } 1^{\text {st }} \text { IE Research Congress, February } \\
\text { 26, 2009, Cebu City, Philippines. }\end{array}$ & 12 \\
\hline $\begin{array}{l}\text { SY 2006-2007 } \\
\text { Transformational and Transactional Leadership Styles } \\
\text { of the Nursing Student Leaders: Enhanced Leadership } \\
\text { Training Program by Dr. Mauro Allan P. Amparado. } \\
\text { Presentor, } 10^{\text {th }} \text { East Asian Forum of Nursing Scholars, } \\
\text { February } 23,2007 \text {, Dumaguete City, Philippines. }\end{array}$ & 13 \\
\hline $\begin{array}{l}\text { Transformational and Transactional Leadership Styles } \\
\text { of the Nursing Student Leaders: Enhanced Leadership } \\
\text { Training Program by Dr. Mauro Allan P. Amparado } \\
\text { Presentor, PAGE VII Regional Assembly, September } \\
8,2007 \text {, Sacred Heart Center, Cebu City, Philippines }\end{array}$ & 14 \\
\hline RESEARCHES ACCEPTED FOR PUBLICATION & \\
\hline $\begin{array}{l}\text { Ontologies for Self-regulated Learning by Moma De } \\
\text { La Torre and Raymund Sison. } \\
\text { Published in the journal Towards Sustainable and } \\
\text { Scalable Educational Innovations Informed by the } \\
\text { Learning Sciences, } 2005 \text {. }\end{array}$ & 15 \\
\hline
\end{tabular}




\begin{tabular}{|l|c|}
\hline \multicolumn{1}{|c|}{ CONTENT } & PAGE \\
\hline $\begin{array}{l}\text { Rigalu: The Ritual of Gift- Giving among the Sukdan } \\
\text { Shamans of Northen Bohol: A Study in } \\
\text { Anthropological Ethics and Poetry by Dr. Ulysses B. } \\
\text { Aparece }\end{array}$ & \\
& \\
Published in the Philippine Quarterly of Culture and \\
Society, Volume 34, Number 2, 2006.
\end{tabular}




\title{
UNIVERSITY OF CEBU \\ UNIVERSITY RESEARCH CENTER
}

\author{
FOLDER D \\ EXTERNALLY-FUNDED FACULTY RESEARCH GRANTS
}

\section{TABLE OF CONTENTS}

\begin{tabular}{|l|c|}
\hline \multicolumn{1}{|c|}{ CONTENT } & PAGE \\
\hline Summary of Externally-funded Faculty Researches & 1 \\
\hline Notice to Proceed from CHED and Terms of & 3 \\
Reference & \\
Enhancing Educational Thrusts for Development, & \\
CHED Zonal Research Center Grant-in-Aid Research & \\
Project, Dr. Erlinda P. Barcelo (Project Leader) & \\
$1^{\text {st } \text { Project: Factors Related to the Maritime Pre- }}$ \\
apprenticeship Phase: A Proposed Maritime Pre- \\
apprenticeship Program. \\
Dr. Maria Salud M. De Los Santos (Study Leader) \\
Dr. Glenn R. Andrin (Member) \\
Mr. Alberto C. Felisilda Jr. (Member) \\
Dr. Ily E. Abella (Member) \\
Dr. Nelson Esguerra (Member) \\
2nd Project: Retrieving Francisco Dagohoy through the \\
Narratives of the Sukdan Shamans \\
Dr. Ulysses B. Aparece (Study Leader) \\
Mr. Delfin Cabañero (Member) \\
$3^{\text {rd Project: The Status of Extension Programs of HEIs }}$ \\
in Cebu City: Basis for the Development of \\
Capability-building Programs. \\
Ms. Rosario E. Sequitin (Study Leader) \\
Sr. Sandra G. Clemente (Member) \\
\hline Contract for Grant-in-aid, Enhancing Educational \\
Thrusts for Development \\
\hline Terms of Reference, Situational Analysis of Selected \\
Micro Enterprises in the Underground Economy of \\
Cebu City. \\
2010 CHED Zonal Research Center Grant-in-Aid \\
Study \\
Ms. Maria Fe P. Imbong (Study Leader) \\
Dr. Glenn R. Andrin (Member) \\
Mr. Franco B. Imbong (Member) \\
Ms. Rosadelma P. Villacastin (Member) \\
\\
\end{tabular}




\begin{tabular}{|l|c|}
\hline \multicolumn{1}{|c|}{ CONTENT } & PAGE \\
\hline Terms of Reference, Botika ng Barangay: Its & 22 \\
Contribution to Family Living Standards. & \\
Dr. Daisy R. Palompon & \\
Dr. Mauro Allan P. Amparado & \\
Dr. Marylou B. Ong & \\
Ms. Jezyl T. Cempron and & \\
Mr. Esperidion Corvera. & \\
\hline Terms of Reference, Organizational Citizenship & 24 \\
Behavior of the Private Higher Education Institutions & \\
in Cebu City. & \\
Dr. Cecil S. Gantalao & \\
Dr. Mauro Allan P. Amparado & \\
\hline
\end{tabular}




\section{UNIVERSITY OF CEBU \\ UNIVERSITY RESEARCH CENTER}

FOLDER I

INSTITUTIONAL AND URC THREE-YEAR DEVELOPMENT PLAN

TABLE OF CONTENTS

\begin{tabular}{|l|c|}
\hline \multicolumn{1}{|c|}{ CONTENT } & PAGE \\
\hline $\begin{array}{l}\text { Institutional Three-year Development Plan, } \\
\text { SY 2011-2014 }\end{array}$ & 1 \\
\hline $\begin{array}{l}\text { Institutional Five-year Development Plan, } \\
\text { SY 2006-2011 }\end{array}$ & 18 \\
\hline Financial Statement of Research Grants and Seminars & 37 \\
\hline Financial Statement of Supplies and Equipment & 39 \\
\hline URC Three-year Development Plan, SY 2011-2014 & 46 \\
\hline Calendar of Activities SY 2011-2012 & 51 \\
\hline Job Description of the University Research Director & 52 \\
\hline Job Description of the University Research Specialist & 52 \\
\hline Job Description of the Campus Research Coordinator & 53 \\
\hline Job Description of the Program Research Coordinator & 53 \\
\hline Existing Faculty Ranking Scheme & 54 \\
\hline Proposed New Faculty Ranking Scheme & 60 \\
\hline
\end{tabular}




\section{UNIVERSITY OF CEBU \\ UNIVERSITY RESEARCH CENTER}

URC MANUAL SY 2011-2012

ISSN 2243-7568

\section{FOLDER NUMBER 5}

- Situational Analysis of Selected Micro Enterprises in the Underground Economy of Cebu City

2010 CHED Zonal Research Center Grant-in-Aid Study

Ms. Maria Fe P. Imbong (Study Leader)

Dr. Glenn R. Andrin (Member)

Mr. Franco B. Imbong (Member)

Ms. Rosadelma P. Villacastin (Member)

- Botika ng Barangay: Its Contribution to Family Living Standards 2009 CHED Zonal Research Center Grant-n-Aid Study

Dr. Daisy R. Palompon (Study Leader)

Dr. Mauro Allan P. Amparado (Member)

Dr. Marylou B. Ong (Member)

Ms. Jezyl T. Cempron (Member)

Mr. Esperidion Corvera (Member)

- Organizational Citizenship Behavior of the Private Higher

Educational Institutions in Cebu City

2010 CHED Zonal Research Center Grant-in-Aid Study

Dr. Cecil S. Gantalao (Study Leader)

Dr. Mauro Allan P. Amparado (Member) 


\title{
UNIVERSITY OF CEBU \\ UNIVERSITY RESEARCH CENTER
}

\author{
URC MANUAL SY 2011-2012 \\ ISSN 2243-7568
}

\section{FOLDER NUMBER 6}

- The First Year Education Students' Learning Style and their Academic Performance

Ms. Moonyen O. Tecson (Researcher)

Ms. Elna B. Sabornido (Researcher)

Accepted paper for the $2^{\text {nd }}$ Internationalization of Higher Education Research Conference, October 21 and 22, 2011, Bacolod City, Philippines.

- Jigsaw Strategy in Teaching and Learning Philippine History and Constitution,

Ms. Cherry G. Tantiado (Researcher)

Accepted paper for the $2^{\text {nd }}$ Internationalization of Higher Education Research Conference, October 21 and 22, 2011, Bacolod City, Philippines.

- UC-METC's Shipboard Maritime Apprenticeship as a Cadet-centered Mechanism towards Environmental Pollution Abatement

Mr. Noel P. Crucio (Researcher)

Capt. Arnel N. Malaga (Researcher)

Mr. Alberto C. Felisilda Jr. (Researcher)

Mr. Robert M. Maluya

Accepted paper for the $2^{\text {nd }}$ Internationalization of Higher Education Research Conference, October 21 and 22, 2011, Bacolod City, Philippines.

- Botika ng Barangay: Its Contribution to Family Living Standards 2009 CHED Zonal Research Center Grant-n-Aid Study

Dr. Daisy R. Palompon (Study Leader)

Dr. Mauro Allan P. Amparado (Member)

Dr. Marylou B. Ong (Member)

Ms. Jezyl T. Cempron (Member)

Mr. Esperidion Corvera (Member)

Accepted paper in the December 2010 Volume 6 Number 2 Liceo Journal of Higher Education Research.

- Students' Entrepreneurship in the College of Business Administration and Accountancy, University of Cebu Main Campus

Ms. Rhea G. Fabrica (Researcher)

Mr. Eric P. Gabutin (Researcher)

Accepted paper for the $4^{\text {th }}$ Taiwan-Philippines Academic Conference. 


\section{UNIVERSITY OF CEBU UNIVERSITY RESEARCH CENTER}

\section{CALENDAR OF ACTIVITIES SY 2011-2012}

\begin{tabular}{|c|c|}
\hline June 10, 2011 & $\begin{array}{l}\text { In-service Training for Research; Formulation of } \\
\text { Institutional Faculty Research (IFR) Agenda }\end{array}$ \\
\hline July 18, 2011 & Submission of IFR Proposals (UC-Banilad) \\
\hline July 19, 2011 & Submission of IFR Proposals (UC-LM) \\
\hline July 20, 2011 & Submission of IFR Proposals (UC-METC) \\
\hline July 21, 2011 & Submission of IFR Proposals (UC-Main) \\
\hline July 22, 2011 & $\begin{array}{l}\text { Asian Public Intellectuals (API) Orientation; } \\
\text { Formulation of Program Research Agenda }\end{array}$ \\
\hline August 26, 2011 & MOA Signing and Orientation of IFR \\
\hline September 5, 2011 & $3^{\text {rd }}$ UC-Banilad Faculty Research Forum \\
\hline September 15, 2011 & Proposal Hearing of IFR (UC-Main) \\
\hline September 16, 2011 & Proposal Hearing of IFR (UC-METC) \\
\hline September 22, 2011 & Proposal Hearing of IFR (UC-Banilad) \\
\hline September 23, 2011 & Proposal Hearing of IFR (UC-LM) \\
\hline September 30, 2011 & $\begin{array}{l}\text { Deadline of } 2011 \text { PACUCOA Case Study } \\
\text { Competition }\end{array}$ \\
\hline October 28, 2011 & $\begin{array}{l}\text { Submission of students' hard bound research } \\
\text { projects for } 1^{\text {st }} \text { Semester SY } 2011-2012\end{array}$ \\
\hline December 3, 2011 & $\begin{array}{l}\text { Christmas Party (University Research Center and } \\
\text { Campus Research Offices) }\end{array}$ \\
\hline January 13, 2012 & $\begin{array}{l}1^{\text {st }} \text { Research Office Research and Statistics Lecture } \\
\text { (UC-Banilad) }\end{array}$ \\
\hline January 26, 2012 & Oral Defense of IFR (UC-Main) \\
\hline January 27,2012 & Oral Defense of IFR (UC-METC) \\
\hline February 2, 2012 & Oral Defense of IFR (UC-Banilad) \\
\hline February 3, 2012 & Oral Defense of IFR (UC-LM) \\
\hline February 10, 2012 & $\begin{array}{l}1^{\text {st }} \text { Research Office Research and Statistics Lecture } \\
\text { (UC-LM) }\end{array}$ \\
\hline February 17,2012 & $\begin{array}{l}1^{\text {st }} \text { Research Office Research and Statistics Lecture } \\
\text { (UC-METC) }\end{array}$ \\
\hline February 24,2012 & $2^{\text {nd }}$ URC Research Forum \\
\hline March 3, 2012 & $1^{\text {st }}$ URC Research and Statistics Lecture \\
\hline March 30, 2012 & $\begin{array}{l}\text { Submission of students' hard bound research } \\
\text { projects for } 2^{\text {nd }} \text { Semester SY 2011-2012 }\end{array}$ \\
\hline April 14, 2012 & Submission of completed IFR SY 2011-2012 \\
\hline April 27, 2012 & $2^{\text {nd }}$ URC Research and Statistics Lecture \\
\hline May 4, 2012 & Submission of 2012 IFR Proposals (UC-Banilad) \\
\hline May 5, 2012 & Submission of 2012 IFR Proposals (UC-LM) \\
\hline May 11,2012 & Submission of 2012 IFR Proposals (UC-METC) \\
\hline May 12, 2012 & Submission of 2012 IFR Proposals (UC-Main) \\
\hline May 18,2012 & $\begin{array}{l}\text { Release of NOVUS Research Journal } \\
\text { SY 2011-2012 }\end{array}$ \\
\hline
\end{tabular}




\section{UNIVERSITY OF CEBU \\ UNIVERSITY RESEARCH CENTER \\ STANDARD PROCEDURE NUMBER 3 \\ RESEARCH METHODS AND THESIS WRITING}

\section{A. METHODS OF RESEARCH $\left(1^{\mathrm{ST}}\right.$ COURSE)}

1. The 1st Research subject in the curriculum (Research Methods) shall be under the supervision of the General Education Coordinator, in consultation with the College Dean/Chairperson and the Program Research Coordinator (PRC).

2. The instructor who shall teach Research Methods must be at least a master's degree holder (Thesis program).

3. The syllabus for Research must be aligned with all colleges in all the campuses of the university.

4. Only university-approved Research textbooks shall be used by the instructors.

5. The research outputs of the group of students (at most 5 students in a group) must only be research proposals.

6. No panel defense shall be conducted in any Research Methods class. Instead, proposal presentations are encouraged, the venue of which shall be inside the campus only. The presentation involves the instructor and the class only.

7. Collection of fees for whatever purpose is strictly prohibited.

8. Colors of the colleges are:

$\begin{array}{lll}\text { Arts } & - & \text { Violet } \\ \text { Business Administration } & - & \text { Red } \\ \text { Computer Studies } & - & \text { Light Blue } \\ \text { Criminology } & - & \text { Yellow } \\ \text { Customs Administration } & - & \text { Orange } \\ \text { HRM } & - & \text { Brown } \\ \text { Education } & - & \text { White } \\ \text { Engineering } & - & \text { Black } \\ \text { Marine Engineering } & - & \text { Dark Blue } \\ \text { Marine Transportation } & - & \text { Dark Blue } \\ \text { Nursing } & - & \text { Green }\end{array}$

9. Each group shall submit 3 hard-bound copies of their research proposals to the University Research Center (URC) before the end of the semester. 
10. URC shall create a masterlist and inventory of all completed proposals. All hard-bound copies will be endorsed to the University Library for public use.

\section{B. THESIS WRITING (2 $2^{\mathrm{ND}}$ COURSE)}

1. The 2nd Research subject in the curriculum (Thesis Writing) shall be under the supervision of the College Dean/Chairperson, in consultation with the Program Research Coordinator (PRC).

2. The instructor who shall teach Research Methods must be at least a master's degree holder (thesis program).

3. The syllabus for Thesis Writing must be aligned with all colleges in all the campuses of the university.

4. Only university-approved textbooks shall be used by the instructor.

5. The research outputs of the students must be in the form of a full-blown thesis.

6. Proposal hearing shall be done at the beginning of the semester, during the Prelim Grading Period. The group in the Research Methods class shall continue to be the same group in the Thesis Writing class. The 4 panel members are: 1 PRC (Chairman); 2 members; 1 adviser. The instructor of the class is the 2 nd member of the panel, but at no extra expense on the students.

7. An Oral Defense shall be conducted during the Final Grading Period. The panel members shall be the same members during the proposal hearing.

8. The College may or may not collect the fees and disburse them to the members of the panel as follows, but shall not exceed:

$\begin{array}{lll}\text { Adviser } & - & \text { P500.00 per group (P200.00 proposal/P300.00 orals) } \\ \text { Chairman } & - & \text { P500.00 per group (P200.00 proposal/P300.00 orals) } \\ \text { Member 1 } & - & \text { P300.00 per group (P100.00 proposal/P200.00 orals) } \\ \text { Member 2 } & - & \text { No payment (He/she is the instructor of the class) } \\ \text { Statistician } & - & \text { P500.00 per group (to be paid during orals) } \\ \text { Censor } & - & \text { P500.00 per group (to be paid during orals) } \\ \text { Total } & - & \text { P2,300.00 per group }\end{array}$

9. Instructors are requested to use Standard Form Number 5 (Proposal Hearing Rating Sheet) and Standard Form Number 6 (Oral Defense Rating Sheet) for grading research projects.

10. The College shall assign the date and venue for the Proposal Hearing and 
Oral Defense. Venues outside the campus are not allowed. Gift-giving by the students to the panel is discouraged.

11. Colors of the colleges are:

$\begin{array}{lll}\text { Arts } & - & \text { Violet } \\ \text { Business Administration } & - & \text { Red } \\ \text { Computer Studies } & - & \text { Light Blue } \\ \text { Criminology } & - & \text { Yellow } \\ \text { Customs Administration } & - & \text { Orange } \\ \text { HRM } & - & \text { Brown } \\ \text { Education } & - & \text { White } \\ \text { Engineering } & - & \text { Black } \\ \text { Marine Engineering } & - & \text { Dark Blue } \\ \text { Marine Transportation } & - & \text { Dark Blue } \\ \text { Nursing } & - & \text { Green }\end{array}$

12. Each group shall submit 3 hard-bound copies of their research proposals to the University Research Center before the end of the semester.

13. URC shall create a masterlist and inventory of all completed proposals. All hard-bound copies will be endorsed to the University Library for public use.

Prepared by: Dr. Mauro Allan P. Amparado

Date of revision: June 1, 2012 